

\title{
SECTORAL MONEY DEMAND AND THE GREAT DISINFLATION IN THE US
}

\author{
by Alessandro Calza ' \\ and Andrea Zaghini²
}

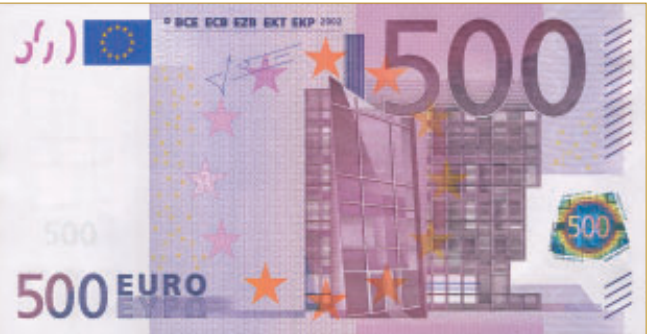

In 2010 all ECB

publications

feature a motif

$€ 500$ banknote.

NOTE: This Working Paper should not be reported as representing the views of the European Central Bank (ECB).

The views expressed are those of the authors and do not necessarily reflect those of the $E C B$.

This paper can be downloaded without charge from http://www.ecb.europa.eu or from the Social Science Research Network electronic library at http://ssrn.com/abstract_id $=1625846$. 
CC European Central Bank, 2010

\section{Address}

Kaiserstrasse 29

60311 Frankfurt am Main, Germany

Postal address

Postfach 160319

60066 Frankfurt am Main, Germany

Telephone

+496913440

Internet

http://www.ecb.europa.eu

Fax

+496913446000

All rights reserved.

Any reproduction, publication and reprint in the form of a different publication, whether printed or produced electronically, in whole or in part, is permitted only with the explicit written authorisation of the ECB or the authors.

Information on all of the papers published in the ECB Working Paper Series can be found on the ECB's website, http://www. ecb.europa.eu/pub/scientific/wps/date/ html/index.en.html

ISSN 1725-2806 (online) 


\section{CONTENTS}

Abstract

Executive summary

1 Introduction

2 Money demand and welfare

3 Data issues

4 Sectoral money demand

5 Welfare cost estimations

6 Concluding remarks

Notes

References

Tables 


\begin{abstract}
Estimates of the welfare costs of inflation based on Bailey (1956) are typically computed using aggregate money demand models. Yet, the behavior of money demand may vary across sectors. Thus, the impact on welfare of inflation regime shifts may differ between households and firms. We specifically investigate the sectoral welfare implications of the shift from the Great Inflation to the present regime of low and stable inflation. For this purpose, we estimate different functional specifications of money demand for US households and non-financial firms using flow-of-fund data covering four decades. We find that the benefits were significant for both sectors.
\end{abstract}

JEL classification: E31, E41.

Keywords: welfare cost of inflation, flow of funds data, demand for money. 


\section{Executive Summary}

At the height of the Great Inflation in 1980, the three-month T-bill interest rate stood at $15 \%$. By the end of the 1990s, it had declined by around two-thirds. There is general consensus that moving from a regime in which one of the closest empirical proxies for a short-term risk-free rate was a double-digit rate to one in which both nominal interest rates and inflation are low and stable has yielded substantial welfare benefits. Indeed, a substantial body of literature has shown that high and volatile inflation entails a number of economic and social costs, mainly arising from the inefficient allocation of resources due to increased uncertainty and distortions to relative prices.

A specific source of inflation-related welfare costs - the so-called "shoe-leather costs" - arises when agents inefficiently manage their holdings of monetary balances for transaction purposes because of inflation. The traditional way to measure the welfare loss arising from shoe-leather costs is based on the methodology by Bailey (1956). He suggests that such costs can be measured by the area underlying the inverse money demand function, which represents the lost consumer surplus (net of seigniorage revenues) that could be gained from reducing the positive nominal interest rate to zero. Intuitively, the rationale of Bailey's approach is that - assuming that monetary balances yield direct utility via liquidity services and that higher nominal interest rates increase the opportunity cost of holding monetary balances - higher expected inflation will lead to agents inefficiently economising on their monetary balances, via its impact on nominal interest rates.

A large number of studies have used Bailey's approach to estimate the welfare costs of inflation arising from distortions to money demand. For instance, Fischer (1981) estimates the cost of a $10 \%$ inflation rate at around $0.3 \%$ of US GNP per year. A review by Gillman (1995) reports significantly larger estimates, ranging between $0.85 \%$ and $3 \%$ of US income, for the same inflation rate. More recently, an influential study by Lucas (2000) using annual data covering most of the twentieth century argues that the welfare gains from reducing inflation could be significant. In particular, reducing the annual inflation rate from $10 \%$ to zero would lead to welfare gains of slightly less than 1\% of GNP per year in perpetuity. By contrast, a paper by Ireland (2009), focusing on the sample 1980-2004, concludes that the welfare gains 
from eliminating inflation altogether would be significantly lower in the current monetary regime of low interest rates. Likewise, Mulligan and Sala-i-Martin (2000) suggest that the welfare costs at low inflation rates are limited, once one takes into account changes in portfolio allocation behavior across inflation regimes.

Estimations of the welfare costs of inflation are usually based on aggregate money demand functions, i.e. equations representing the equilibrium demand for real monetary holdings for the US economy as a whole. However, empirical evidence (e.g. Goldfeld 1976, and Jain and Moon 1994) shows that money demand behavior significantly differs across US sectors, suggesting that the application of Bailey's (1956) methodology to measure shoe-leather costs may yield different results across sectors.

Allowing for sectoral heterogeneity in the estimation of money demand functions is potentially very important for policy purposes since it implies that different categories of agents may have diverging views on the welfare losses associated with living in a high inflation environment or on the benefits stemming from moving to a low inflation environment. In particular, US households and firms may differently value the permanent welfare benefits that they secured with the regime shift from the Great Inflation to the current environment of moderate and stable inflation and interest rates. The purpose of this paper is to analyse the welfare impact for households and firms of the modern disinflation using Bailey's methodology. In order to do so, we estimate different functional specifications of sectoral money demand for households and nonfinancial firms, using flow of funds data covering the period from 1959 to 2006. Our estimates of the welfare gains for households amount to between approximately $1 / 6 \%$ and $1 / 3 \%$ of annual private consumption (depending on whether a log-log or a semi$\log$ function is used) and for firms between $1 / 9 \%$ and $1 / 4 \%$ of business GDP, thus suggesting that households might have benefited slightly more than firms from the shift to the present low inflation regime. However, once we rescale these figures to a common transaction variable, the estimated sectoral welfare gains turn out to be of similar magnitude across sectors. Once we aggregate across sectors, our results are closer to the inflation costs reported by Fischer (1981) and Ireland (2009) than to those by Lucas (2000). 


\section{$1 \quad$ Introduction $^{1}$}

At the height of the Great Inflation in 1980, the three-month T-bill interest rate stood at $15 \%$. By the end of the 1990s, it had declined by around twothirds. There is general consensus that moving from a regime in which one of the closest empirical proxies for a short-term risk-free rate was a double-digit rate to one in which both nominal interest rates and inflation are low and stable has yielded substantial welfare benefits. Indeed, a substantial body of literature has shown that high and volatile inflation entails a number of economic and social costs, mainly arising from the inefficient allocation of resources due to increased uncertainty and distortions to relative prices. Additional sources of welfare costs associated with inflation include high risk premia, the interaction between inflation and the tax code, inefficient distraction of resources from production of goods to financial activities, lower capital accumulation and arbitrary redistribution of wealth (see for instance Driffill et al. 1990, and Fischer 1995).

A specific source of inflation-related welfare costs - the so-called "shoeleather costs" - arises when agents inefficiently manage their holdings of monetary balances for transaction purposes because of inflation. The traditional way to measure the welfare loss arising from "shoe-leather costs" is based on the methodology by Bailey (1956). He suggests that such costs can be measured by the area underlying the inverse money demand function, which represents the lost consumer surplus (net of seigniorage revenues) that 
could be gained from reducing the positive nominal interest rate to zero. Intuitively, the rationale is that - assuming that monetary balances yield direct utility via liquidity services and that higher nominal interest rates increase the opportunity cost of holding monetary balances - higher expected inflation will lead to agents inefficiently economising on their monetary balances, via its impact on nominal interest rates.

A large number of studies have used Bailey's approach to estimate the welfare costs of inflation arising from distortions to money demand. For instance, Fischer (1981) estimates the cost of a $10 \%$ inflation rate at around 0.3\% of US GNP per year. A review by Gillman (1995) reports significantly larger estimates, ranging between $0.85 \%$ and $3 \%$ of US income, for the same inflation rate. More recently, an influential study by Lucas (2000) using annual data covering most of the twentieth century argues that the welfare gains from reducing inflation could be significant. In particular, reducing the annual inflation rate from $10 \%$ to zero would lead to welfare gains of slightly less than $1 \%$ of GNP per year in perpetuity. By contrast, a paper by Ireland (2009), focusing on the sample 1980-2004, concludes that the welfare gains from eliminating inflation altogether would be significantly lower in the current monetary regime of low interest rates. Likewise, Mulligan and Sala-i-Martin (2000) suggest that the welfare costs at low inflation rates are limited, once one takes into account changes in portfolio allocation behavior across inflation regimes. ${ }^{2}$

Estimations of the welfare costs of inflation are usually based on aggregate 
money demand functions, i.e. equations representing the equilibrium demand for real monetary holdings for the US economy as a whole. ${ }^{3}$ Yet, Goldfeld (1976) and Jain and Moon (1994) show that money demand behavior significantly differs between US households and firms. Indeed, differences in terms of motives for demanding monetary holdings, cash management practices, patterns of usage of banking and financial products, access to alternative payments technology, etc. are likely to result in different sectoral responses to variations in the key money demand determinants, such as scale variables and opportunity cost measures.

Thus, one would expect that the welfare costs associated with high inflation should also differ across the different sectors of the economy. This issue is important since it implies that different categories of agents may have a different assessment of the welfare losses associated with high-inflation or, conversely, of the welfare gains arising from moving to a low inflation regime. In particular, there is consensus that the end of the Great Disinflation and the shift to the present low inflation regime has yielded substantial welfare gains to the population at large, but we do not know much about how the magnitude of these benefits compares across different sectors. Of course, it could be argued that to the extent that firms are owned by domestic households, also the costs of inflation of firms may be eventually borne by the latter. However, the objective of this work is to provide a quantitative assessment of the shoe-leather costs that are directly related to the individual sectors. 
The purpose of this paper is specifically to analyse the welfare impact for households and firms of the modern disinflation using Bailey's methodology. In order to do so, we perform a sectoral analysis of the welfare costs of inflation using different specifications of money demand models for households and firms estimated on the basis of flow-of-funds data over the period from 1959 to 2006. To preview our results, we estimate stable long-run money demand relationships for both sectors and we find that both households and firms benefited significantly from moving to the present low inflation regime. The welfare gains represent a greater share of the transaction variable for households than firms; however, once rescaled to a common transaction variable, the welfare gains of the two sectors turn out to be of a comparable size. In addition, our aggregate results are closer to the inflation costs reported by Fischer (1981) and Ireland (2009) than those by Lucas (2000).

The paper is structured as follows. In Section 2 we briefly recall Bailey's approach to the measurement of the welfare cost of inflation. Section 3 deals with some relevant data issues. Section 4 presents the results of estimates of a double-log and a semi-log money demand function for both US households and firms. Section 5 evaluates the welfare gains from reducing inflation to zero and Section 6 draws some conclusions. 


\section{Money demand and welfare}

An issue that has received significant attention in the literature on the welfare costs of inflation is the choice of functional form for the long-run money demand relationship. The two main competing specifications are: 1) Meltzer's (1963) log-log function and 2) Cagan's (1956) semi-log function. The log-log function is specified as follows:

$$
\log (m)=\log (A)+\beta \log (y)-\eta \log (r)
$$

where $m$ are monetary balances, $y$ is a measure of the volume of transactions, $r$ is the nominal interest rate (the opportunity cost of holding the non-interest bearing asset), $A>0$ is a constant, $\beta$ and $\eta$ denote the elasticities (in absolute values) with respect to the transaction variable and the interest rate, respectively. Money and scale variables are typically measured in real terms. Similarly, the semi-log function is as follows:

$$
\log (m)=\log (B)+\beta \log (y)-\xi r
$$

where $B>0$ is a constant and $\xi$ denotes the absolute value of the interest rate semi-elasticity.

Applying Bailey's method to the log-log money demand function (1), we obtain the following measure of the welfare costs associated with a positive 
nominal interest rate $r$ :

$$
w(r)=A y^{\beta-1}\left(\frac{\eta}{1-\eta}\right) r^{1-\eta}
$$

while the corresponding measure for the semi-log money demand equation (2) takes the form:

$$
w(r)=\frac{B}{\xi} y^{\beta-1}\left[1-(1+\xi r) e^{-\xi r}\right]
$$

In practical terms, these measures - the so-called "welfare triangles" - are obtained as integrals of the inverse money demand function (i.e. expressed as function of the nominal interest rate) on the interval $[0, r]$. A positive value of the nominal interest rate as a result of expected inflation implies a positive opportunity cost of holding money and leads to the monetary balances of agents falling below their optimal level. ${ }^{4}$ Thus, the "welfare triangle" measures the consumer surplus lost by agents by inefficiently foregoing services provided by money in facilitating exchanges because of inflation. ${ }^{5}$ Also note that the welfare costs due to living in an economy where the steady state interest rate is $r$ instead of zero are expressed as fractions of the transaction variable.

When the elasticity of money with respect to the transaction variable $(\beta)$ is unitary, the transaction variable drops out of (3) and (4) and, given the estimated parameters of the money demand function, the computation of the welfare triangles for any given level of interest rate is straightforward. When 
the elasticity is different from one, a value of the transaction variable must be specified in order to be able to calculate the welfare costs (Gillman 1995).

The behavior of the two functions significantly differs under very low levels of the interest rate. In particular, as the interest rate approaches zero, the demand function reaches a finite level under the semi-log specification, while it is asymptote to infinity under the log-log function. This difference in behavior at the zero level has implications for the calculation of the welfare gains from implementing a zero inflation policy or the Friedman rule.

Lucas (2000) argues that the log-log functional form (1) provides a superior description of the historical behavior of US money demand and a more precise calculation of the welfare costs of inflation, particularly at low interest rates. In addition, he notes that, in the framework of the shopping-time model of money demand determination by McCallum and Goodfriend (1987) and for reasonable estimates of the interest rate elasticity, the log-log money demand equation is consistent with inventory-theoretic money demand models, such as the Baumol-Tobin model. Chadha et al. (1998) concur on the theoretical superiority of the log-log form. Also using McCallum and Goodfriend's model, these authors show that the choice of any well-behaved utility function and transactions technology (e.g. Cobb-Douglas, CES and translog functions) is likely to result in a log-log specification of long-run money demand.

While theoretical considerations and historical empirical evidence seem to support the log-log functional form, Ireland (2009) has recently argued that 
the post-1980 data are better described by a semi-log function. In the author's view, the monetary policy regime shift following the appointment of Paul Volcker as Chairman of the Federal Reserve in 1979 and the reforms to the regulatory framework introduced by the Depository Institutions Deregulation and Monetary Control Act in 1980 led to a shift in money demand behavior warranting a change in the preferred specification.

As our study focuses on a sample period (1959-2006) which entirely comprises that examined by Ireland (1980-2006), but is shorter and only partly overlapping with Lucas' (1900-1994), it is difficult to tell ex-ante which of the two alternative specifications is likelier to prove more appropriate. Thus, in the empirical analysis we consider both specifications and we separately assess their associated welfare cost functions.

\section{Data issues}

The empirical exercise is based on a sample period spanning from the first quarter of 1959 (the earliest date for which data on sectoral monetary holding are available) to the fourth quarter of 2006. Since we want to study the welfare gains of the modern disinflation for different sectors of the US economy, it is important to ascertain whether this sample period adequately captures the shift from the double-digit inflation rates during the Great Inflation to the present regime of low and stable inflation. The sample pre-dates the switch to the Great Inflation by around one decade, indicating that the 
starting date is adequate. In addition, based on a review of econometric estimates of trend inflation and surveys on inflation expectations, Mishkin (2007) argues that the process of disinflation and the re-anchoring of long-term inflation expectations was completed by the end of the 1990s, suggesting that the ending date of our sample adequately captures the return to a regime of low and stable inflation. More generally, the chosen horizon provides a sufficiently long coverage of periods of both high and low inflation to allow to draw conclusions about money demand behavior across different inflation regimes.

Sectoral data on holdings of monetary assets by households and nonfinancial corporations are sourced from the Federal Reserve Board's flow of funds accounts. These accounts include statistical information on aggregate sectoral holdings of checkable deposits and currency, by households and nonprofit organizations (Table L.100) and by non-financial firms (Table L.101). In the flow of funds accounts, data on financial assets and liabilities of the household sector are usually estimated as residuals (i.e. by subtracting the holdings of the other sectors from the aggregate values for the economy as a whole and assigning the difference to the household sector). Monetary data are available at a quarterly frequency and refer to end-of-period outstanding amounts and have been seasonally adjusted using the X12-ARIMA seasonal adjustment method. Real balances are obtained by dividing monetary holdings by GDP deflator.

The aggregation of checkable deposits and currency corresponds to the de- 
finition of the monetary aggregate M1 used by Lucas (2000). As for the scale variables, following Jain and Moon (1994), we rely on business sector GDP for firms and personal consumption expenditures for households. Business sector GDP is given by US GDP excluding gross value added of households, of non-profit institutions serving households and of general government. Personal consumption expenditure is a measure of goods and services purchased by US residents. Annualised seasonally adjusted nominal data (in US billions) on business GDP and consumption expenditures are available at a quarterly frequency from the Bureau of Economic Analysis (Tables 1.3.5 and 2.1, respectively), together with the corresponding price index (Tables 1.3.4 and 2.3.4). Finally, the interest rate is the period average of the rate of return on the three-month Treasury bill, sourced from the Federal Reserve Board, and is expressed in percentage points.

An important issue related to the data on monetary holdings is the need to control for the effect on households' checkable deposits of the wide use of retail deposit sweep programs by banks. As explained by Anderson (1995 and 2003), in order to economise on their statutory reserve requirements, starting from January 1994 US banks have used software programmes that "sweep" funds from demand deposits (that are subject to statutory reserve requirements) to money market deposit accounts (a type of savings accounts and, therefore, subject to a zero percent reserve ratio) at the end of each business day. The sweep movements performed by banks involve only reclassifications of the balances in their customers' accounts rather than shifts 
in the demand for money from economic agents, who are likely to perceive themselves to own significantly larger holdings of transaction deposits than reported by banks in their balance sheets. Therefore, in order to understand the money demand behavior of US households, it is essential to add the estimated amount of transaction deposits involved in the retail sweep programs to the holdings of checkable deposits reported in the flow-of-funds statistics. In this paper we use the estimates of transaction deposits affected by the retail sweep programs documented in detail in Cynamon et al. (2006), ${ }^{6}$ that have been used in previous empirical money demand studies (e.g. Dutkowsky and Cynamon 2003, Dutkowsky et al. 2006, and Ireland 2009).

\section{Sectoral money demand}

Equilibrium money demand relationships are conventionally estimated in a cointegration analysis framework. As a preliminary step, the statistical properties of the variables are examined using standard unit root tests (augmented Dickey-Fuller and Phillips-Perron) as well as the KPSS stationarity test. The results - not reported for the sake of brevity - suggest that over the considered sample period all the variables can be modelled as $\mathrm{I}(1)$ in levels.

We test for cointegration using two sets of single-equation tests: (1) the error-correction model (ECM) tests by Zivot (1994) as described by Maddala and Kim (1998); and (2) the Phillips-Ouliaris (1990) residual-based tests. The first Zivot test involves the preliminary estimation of a two-step error 
correction model. The null-hypothesis of no cointegration is then tested by means of a standard $t$-test of the significance of the loading factor of the error correction term. Under the second Zivot test, the ECM is estimated in a single step and the null hypothesis of no cointegration is tested by applying a standard Wald test to the restriction that the variables forming the cointegrating vector can be jointly excluded from the model. The PhillipsOuliaris residual-based tests are conducted by applying the Phillips-Perron $Z_{t}$ and $Z_{q}$ unit root tests to the residuals of the estimated equilibrium equation specified as in (1) or (2). Under the null hypothesis, the residuals contain a unit root and the equation does not represent a cointegrating relationship.

The results of the Zivot tests indicate strong evidence of cointegration for both households and firms, regardless of the choice of specification (Table 1). The evidence is less uniform across sectors and functional specifications when the Phillips-Ouliaris tests are used. Indeed, the results of the tests seem to provide more robust evidence of cointegration for households and firms, when the semi-log specification is used. By contrast, when the log-log specification is used, the null of no cointegration can be rejected only for households (and in this case at a lower significance level than for the semi-log specification).

A recent study by Choi et al. (2008) argues that the failure to detect cointegration using standard cointegration tests may be due to non-stationary measurement error in the variables or the omission of relevant I(1) explanatory variables. Money demand models may be affected by this problem because of the difficulty to measure the holdings of domestic agents or the 
very large number of factors potentially affecting money demand behavior. In particular, the data on monetary holdings by households can be potentially affected by measurement error because of their "residual" nature. In order to address this problem, Choi et al. (2008) propose a cointegration test in the spirit of the Hausman test that specifically accounts for the possibility of spurious regressions arising from non-stationarity of the error in the regression. ${ }^{7}$

We use Choi et al.'s (2008) Hausman-type test to further investigate the log-log specifications, for which the results of the Phillips-Ouliaris test were either not entirely clear-cut (in the case of households) or unfavorable (in the case of firms). The results of the Hausman-type test support the existence of cointegration for the household sector under the log-log specification. By contrast, they provide evidence against the null hypothesis of cointegration for the firm sector when the log-log specification is used. ${ }^{8}$

Overall, the results of our cointegration analysis using different tests is fairly supportive of the existence of cointegration for the household sector, regardless of the specification used. As regards the corporate sector, the empirical evidence is fairly robust for the semi-log specification, but weaker for the log-log specification.

We estimate the long-run sectoral equilibrium money demand functions for households and firms under both functional specifications (1) and (2), using four alternative single-equation estimators: (1) the dynamic OLS method by Saikkonen (1991); (2) the autoregressive distributed lag modelling ap- 
proach by Pesaran and Shin (1999); (3) the fully modified OLS method by Phillips and Hansen (1990); and (4) the Engle and Yoo's (1991) three-step approach to the OLS-based Engle and Granger procedure. The lag specification of the models (as well as of the leads in the case of the dynamic OLS) is chosen using the Akaike Information Criterion.

Tables 2 and 3 report the estimates of the long run coefficients of the money demand functions for households and firms, respectively, under the alternative functional specifications. The estimated long-run coefficients for both the scale variable and the interest rate are statistically significant at the conventional levels, regardless of the functional specification or estimation procedure used. ${ }^{9} \quad$ The estimated coefficients for any given functional form tend to be consistent across estimators (though the ranges of the estimated coefficients are slightly wider for firms than for households), suggesting that the results are fairly robust to the choice of econometric methodology. The signs and magnitude of the coefficients are in all cases consistent with the interpretation of the cointegrating vectors as equilibrium money demand relationships.

Based on this empirical exercise, we are able to estimate long-run money demand functions with statistically significant and plausible coefficients under the alternative functional forms for both the household and the corporate sector. However, given the relatively broad time span covered by the sample period, it is important to test for the stability of the sectoral money demand relationships before moving on to the computation of the welfare costs. For 
this purpose, we use the MeanF and SupF tests for cointegrated regression models - based on the mean and maximum, respectively, of Chow-type statistics for all possible break points - suggested by Hansen (1992). The MeanF test is designed to detect gradual shifts over time that result in model instability, while the SupF test is more appropriate to reveal instability arising from an abrupt regime shift. Since the null hypothesis is stability, a low pvalue of the test statistic (say below 0.10) should be interpreted as indicative of parameter instability. In this empirical application, the tests are based on the fully modified OLS estimates reported in Tables 2 and $3 .^{10}$

The results of the test indicate that the null hypothesis of joint parameter stability of the sectoral models cannot be rejected at the conventional significance levels, suggesting that the models capture fairly stable relationships over the sample period considered.

\section{$5 \quad$ Welfare cost estimations}

In this section, we estimate the welfare gains associated with the transition from a regime of high inflation to one in which inflation is stable at low levels. In order to calculate the welfare triangles, we use the estimates of the longrun coefficients $\beta, \eta$ and $\xi$ in Tables 2 and 3, and calibrate the values of the constants $A$ and $B$ so that they equal the average value over the sample of $m y^{\beta} r^{-\eta}$ and $m y^{\beta} e^{-\xi r}$ (as suggested by Lucas 2000). The estimated long-run coefficients together with the constants define the horizontal position and 
curvature of the money demand functions for each sector.

As mentioned earlier, if the elasticity of money with respect to the transaction variable is different from one, we also need to specify a value for the relevant scale variable. In order to ensure that the welfare calculations at different inflation levels are time-independent, we set the level of the scale variables at their average value over the sample period. Substituting these values and the parameters of the money demand equations in (3) and (4), we can compute the welfare gains associated with a specific level of the interest rate.

At the height of the Great Inflation in 1980, the three-month T-bill rate stood at $15 \%$. According to our estimates, the welfare cost of such level of the nominal interest rate for the US households ranged between $0.23 \%$ and $0.26 \%$ (depending on the estimator used) of annual personal consumption in perpetuity under a log-log function; and between $0.33 \%$ and $0.39 \%$ when a semi-log function is used (see Table 5). For US firms, the welfare costs associated with a $15 \%$ nominal interest rate ranged between $0.16 \%$ and $0.24 \%$ of annual business GDP for the log-log function; and between $0.24 \%$ and $0.31 \%$ under the semi-log function (see Table 6).

Following Volker's disinflation in the early 1980s, the US economy gradually moved towards a regime of moderate and stable inflation during which the nominal inflation rate declined to low single-digit figures. By 1999, the 3-month T-bill rate had decreased to around 5\%. Our estimates suggest that the sectoral welfare gains from this favorable regime shift were non negli- 
gible. Indeed, we estimate that the welfare gains for households from the reduction in nominal interest rate from $15 \%$ to $5 \%$ amounted to between $0.14 \%$ and $0.16 \%$ (depending on the estimator used) of annual private consumption under a log-log function and to between $0.29 \%$ and $0.34 \%$ under a semi-log specification. The welfare gains were also non-negligible for firms: 0.09\%-0.13\% of business GDP under the log-log specification compared to 0.21\%-0.26\% under the semi-log specification.

How do our results compare with other recent studies, such as Lucas (2000) and Ireland (2009)? These studies typically report estimates of the welfare gains from reducing the inflation rate from $10 \%$ to $0 \%$. Assuming a steady-state real interest rate of $3 \%$ (broadly consistent with estimates of the natural interest rate at the end of the 1990s by Laubach and Williams 2003), this would be equivalent to estimating the welfare gains from bringing the nominal interest rate from $r=13 \%$ to $r=3 \%$. Welfare measures are usually expressed as a fraction of the scale variable and studies focusing on the US economy as a whole typically refer to GDP. By contrast, in our study the welfare measures are expressed in terms of units of a smaller aggregate which represents the most relevant measure of the transaction volume for the sector under consideration (specifically, private consumption for households and business GDP for firms). Thus, in order to compare our welfare measures with other studies, we first need to rescale them to GDP units. This is simply done by using the average ratio of each sectoral scale variable to GDP over the sample period. Table 7 presents the rescaled values of the sectoral welfare 
costs obtained using the DOLS procedure. ${ }^{11}$

We estimate the welfare gains for households from a ten percentage point reduction in the inflation rate at $0.10 \%$ of US domestic output under a log-log function and at $0.16 \%$ under a semi-log specification. The welfare gains for firms are very similar: $0.09 \%$ of GDP annual under a log-log specification and $0.15 \%$ under a semi-log function. Thus, once rescaled to a common measurement unit, the welfare gains across sectors from moving to the present low inflation regime are estimated at very similar values. In addition, regardless of the sector considered, the estimated welfare gains from reducing inflation are higher under a semi-log specification than under a log-log functional form.

Since the household and the non-financial corporate sector together account for most of US money demand, the aggregation of welfare costs across these two sectors should provide a relatively close approximation of the costs for the economy as a whole. ${ }^{12}$ Depending on the functional specification used, we estimate the aggregate welfare gain from reducing the nominal interest rate from $13 \%$ to $3 \%$ at between $0.19 \%$ of annual GDP under the log-log form and $0.31 \%$ under the semi-log specification. Thus, our estimates are fairly close to those reported by Ireland (2009) and Fischer (1981): $0.25 \%$ and $0.30 \%$ of annual income, respectively; but significantly below the value of $1 \%$ reported by Lucas (2000).

A key source of the difference in the estimated welfare cost is the value of the interest rate elasticity and semi-elasticity. Our empirical exercise for the log-log specification suggests that Lucas's calibrated value of 0.5 is probably 
too high over our shorter but updated sample. Depending on the estimator used, we find that the interest rate elasticity of money demand is around 0.12-0.13 for households and between 0.18 and 0.27 for firms. Thus, even our highest estimate of the more interest-rate sensitive sector is about half the value used by Lucas for the calibration of the US aggregate money demand. Also in the case of the semi-log function, we find that the value used by Lucas to calibrate his money demand function (7) is probably too high. In fact, all our estimates of the interest rate semi-elasticity for the household sector (ranging between 2.520 and 3.038) and most of those for the non-financial corporate sector (ranging between 4.558 and 6.280) are much smaller than Lucas' value. Similarly, differences in sample coverage and estimated interest rate semi-elasticities may help to explain the (much smaller) gap between our estimates of welfare costs and those by Ireland (2009). Indeed, using a shorter sample period than ours, Ireland estimates the aggregate interest rate semi-elasticity at close to 2 .

Finally, Table 7 shows that the sectoral welfare costs associated with $r=3$ are fairly small, particularly when the semi-log specification is used. This finding is consistent with Ireland's (2009) conclusion that, as far as shoeleather costs are concerned, the additional welfare improvements stemming from implementing a zero inflation policy rather than targeting a low but still positive inflation rate (as the Fed currently does) would be limited. ${ }^{13}$ 


\section{Concluding remarks}

This paper presents empirical estimates of the welfare cost of inflation in the US economy in the spirit of the literature initiated by Bailey (1956) and Friedman (1969) and, more recently, revisited by Lucas (2000) and Ireland (2009). This literature focuses on a specific source of inflation-related welfare losses: the shoe-leather costs that arise when agents inefficiently economise on their monetary balances for transaction purposes because of positive inflation.

The main innovation of the paper is to look at the issue from a sectoral perspective. Indeed, estimates of the welfare costs of inflation are usually based on money demand functions for the economy as a whole. However, empirical evidence (e.g. Goldfeld 1976, and Jain and Moon 1994) shows that money demand behavior significantly differs across US sectors, suggesting that the application of Bailey's (1956) methodology to measure shoe-leather costs may yield different results across sectors.

Allowing for sectoral heterogeneity in the estimation of welfare costs of inflation is potentially very important for policy purposes since it implies that different categories of agents may have diverging views on the welfare losses associated with living in a high inflation environment or on the benefits stemming from moving to a low inflation environment. In particular, US households and firms may differently value the permanent welfare benefits that they secured with the regime shift from the Great Inflation to the current 
environment of moderate and stable inflation and interest rates.

We provide a quantitative assessment of the sectoral differences in the welfare gains from such regime shift. In order to do so, we estimate different functional specifications of sectoral money demand for households and nonfinancial firms, using flow of funds data covering four decades. Our estimates of the welfare gains for households amount to between approximately $1 / 6 \%$ and $1 / 3 \%$ of annual private consumption (depending on whether a log-log or a semi-log function is used) and for firms between $1 / 9 \%$ and $1 / 4 \%$ of business GDP, thus suggesting that households might have benefited slightly more than firms from the shift to the present low inflation regime. However, once we rescale these figures to a common transaction variable, the estimated sectoral welfare gains turn out to be of similar magnitude across sectors.

A limitation of this study is of course that, by focusing on the shoe-leather costs, it follows a partial-equilibrium approach to measuring the welfare costs of inflation. Some authors (e.g. Dotsey and Ireland 1996) have argued that, by looking only at a specific source of distortions, Bailey's (1956) approach may significantly underestimate the true cost of inflation. It would be interesting to investigate in future research how the sectoral welfare costs of inflation vary in a general equilibrium framework. 


\section{Notes}

${ }^{1}$ We are grateful to Masao Ogaki and to Giuseppe Grande, Paul Kramp, Qiang Li, Francesco Lippi and an anonymous referee for many interesting suggestions and comments. The views expressed in this paper are those of the authors and do not necessarily reflect the opinions of Banca d'Italia or the European Central Bank.

${ }^{2}$ Based on household survey data, the authors argue that when interest rates are low, the interest rate elasticity of aggregate money demand becomes very small since only a limited fraction of households participates in financial markets due to the reduced incentive to hold interest-bearing assets. As a result, when nominal interest rates are close to zero, money demand hardly reacts to changes in interest rates, so that reducing inflation can no longer bring significant welfare gains via its stimulating effect on monetary balances.

${ }^{3}$ Mulligan and Sala-i-Martin's (2000) study on US households is an exception.

${ }^{4}$ According to the Friedman's (1969) rule, the optimal amount of money is given by the level of money demand in correspondence to a zero nominal interest rate, which requires a deflation rate equal to the real rate of return on capital.

${ }^{5}$ Craig and Rocheteau (2005) point out that an alternative approach to measuring the welfare cost of inflation based on the search theory of monetary exchange yields similar result to Bailey's welfare triangles only under the 
assumption of perfectly competitive prices. However, if one allows for imperfect competition and assumes that firms have some degree of market power, the welfare triangles may underestimate the true cost of inflation.

${ }^{6}$ The data can be downloaded from http://www.sweepmeasures.com/data.ht a webpage dedicated to the issue of the effect of sweep programs maintained by these three authors.

${ }^{7}$ Like the Hausman test, Choi et al.'s (2008) cointegration test compares two different estimators: (1) the authors' GLS corrected dynamic regression estimator, which is consistent under both the null of cointegrating regression and the alternative hypothesis of spurious regression; and (2) the dynamic OLS by Saikkonen (1991), which is consistent under the null hypothesis only. In practice, the GLS corrected estimator is a first differenced version of the dynamic OLS.

${ }^{8}$ The test statistic for the log-log specification of households (with four lags in levels) is 0.030; the corresponding statistic for firms is 37.850. The test is distributed as $\chi^{2}(2)$ : critical values are 4.61 and 5.99 for the $10 \%$ and $5 \%$ significance levels. The test is for the null hypothesis of cointegration against the alternative hypothesis of spurious regression.

${ }^{9}$ Differences in sample coverage and the definition of the variables diminish the information content of comparisons with previous studies. For instance, using a sample spanning the 1960-90 period Jain and Moon (1994) estimate the consumption elasticity of household M1 holdings at 0.464 , a value slightly below those reported in Table 2. However, these authors' model includes a 
long-term rather a short-term interest rate. No evidence of cointegration is found for the corporate sector over the same sample period. An empirical study by Butkiewicz and McConnell (1995) over the 1952-1990 sample period estimates the interest rate elasticity of the 3-month T-bill rate for the household sector at 0.103 , slightly below our own estimates, but their model includes a different transaction variable (disposable personal income).

${ }^{10}$ The test is computed using a GAUSS code by Bruce Hansen that can be downloaded from his webpage (http://www.ssc.wisc.edu/ bhansen/progs/jbes

${ }^{11}$ No significant changes are obtained when using the other econometric methodologies.

${ }^{12}$ By looking only at the holdings of the two main sectors, we may somewhat underestimate overall welfare costs of inflation. On the other hand, traditional estimates of shoe-leather costs for the economy as a whole may, to some extent, overestimate the costs due to measurement errors (e.g. because of their difficulty to exclude foreign demand for currency).

${ }^{13}$ Feldstein (1997) has argued that the welfare gains from moving to price stability can be substantial even at low inflation levels, when sources of welfare losses other than shoe-leather costs (notably, the interaction between inflation and the tax system) are considered. 


\section{References}

[1] Anderson, Richard A. (1995) "Sweeps distort M1 growth." Monetary Trends, Federal Reserve Bank of St. Louis, November.

[2] Anderson, Richard A. (2003) "Retail deposit sweep programs: Issues for measurement, modeling and analysis." Federal Reserve Bank of St. Louis Working Paper 2003-026A.

[3] Bailey, Martin. (1956) "The welfare cost of inflationary finance." Journal of Political Economy, 64, 93-110.

[4] Butkiewicz, James L., and Margaret M. McConnell. (1995) "The stability of the demand for money and M1 velocity: Evidence from the sectoral data." Quartely Review of Economics and Finance, 35:3, 233-243.

[5] Cagan, Phillip. (1956) "The monetary dynamics of hyperinflation." In Studies in the Quantity Theory of Money, edited by Milton Friedman, pp. 27-117. Chicago: Chicago University Press.

[6] Chadha, Jagjit S., Andrew G. Haldane, and Norbert G.J. Janssen. (1998) "Shoe-leather costs reconsidered." Economic Journal, 108, 363382.

[7] Choi, Chi-Young, Ling Hu, and Masao Ogaki. (2008) "Robust estimation for structural spurious regressions and a Hausman-type cointegration test." Journal of Econometrics, 142, 327-351. 
[8] Craig, Ben and Guillaume Rocheteau (2005) "Rethinking the welfare cost of inflation." Economic Commentary of the Federal Reserve Bank of Cleveland, March 1.

[9] Cynamon, Barry Z., Donald H. Dutkowsky, and Barry E Jones. (2006) "Redefining the monetary aggregates: a clean sweep." Eastern Economic Journal, 32, 661-672.

[10] Dotsey, Michael, and Peter N. Ireland. (1996) "The welfare cost of inflation in general equilibrium." Journal of Monetary Economics, 37, 29-47.

[11] Driffill, John, Grayham E. Mizon, and Alistair Ulph. (1990) "Costs of inflation." In Handbook of Monetary Economics Volume 2, edited by Benjamin M. Friedman and Frank H. Hahn, pp. 1013-1066. Amsterdam: North-Holland.

[12] Dutkowsky, Donald H., and Barry Z. Cynamon. (2003) "Sweep programs: The fall of M1 and rebirth of the medium of exchange." Journal of Money, Credit and Banking, 35:2, 263-279.

[13] Dutkowsky, Donald H., Barry Z. Cynamon, and Barry E Jones. (2006) "U.S. narrow money for the twenty-first century." Economic Inquiry, $44: 1,142-152$.

[14] Engle, Robert F., and Sam Yoo. (1991) "Cointegrated economic series: An overview with new results." In Long-run Economic Relationships, 
edited by Engle Robert F., and Clive W.J. Granger, pp. 237-266. Oxford: Oxford University Press.

[15] Feldstein, Martin. (1997) "The costs and benefits of going from low inflation to price stability." In Reducing Inflation: Motivation and Strategy, edited by Christina Romer, and David H. Romer, pp. 123-166. Chicago: University Chicago Press (for NBER).

[16] Fischer, Stanley. (1981) "Towards an understanding of the costs of inflation: II." Carnegie-Rochester Conference Series on Public Policy, 15, $5-42$.

[17] Fischer, Stanley. (1995) "Modern central banking." In The Future of Central Banking: the Tercentenary Symposium of the Bank of England, edited by Forrest Capie, Charles Goodhart, Norbert Schnadt, and Stanley Fischer, pp. 262-308. Cambridge: Cambridge University Press.

[18] Friedman, Milton. (1969) The Optimal Quantity of Money and Other Essays, pp. 1-50. Chicago: Aldine Publishing Company.

[19] Gillman, Max. (1995) "Comparing partial and general equilibrium estimates of the welfare cost of inflation." Contemporary Economic Policy, $13,60-71$.

[20] Goldfeld, Stephen M. (1976) "The case of the missing money." Brookings Papers on Economic Activity, 3, 683-739. 
[21] Hansen, Bruce E. (1992) "Tests for parameter instability in regressions with I(1) processes." Journal of Business 85 Economic Statistics, 10:3, $321-335$.

[22] Ireland, Peter N. (2009) "On the welfare cost of inflation and the recent behavior of money demand." American Economic Review, 99:3, 10401052.

[23] Jain, Parul, and Choon-Geol Moon. (1994) "Sectoral money demand: A co-integration approach." The Review of Economics and Statistics, 76:1, 196-202.

[24] Laubach, Thomas, and John Williams. (2003) "Measuring the natural rate of interest." The Review of Economics and Statistics, 85:4, 10631070.

[25] Lucas, Robert E. (2000) "Inflation and welfare." Econometrica, 68, 247274.

[26] Maddala, Gangadharrao S., and In-Moo Kim. (1998) Unit Roots, Cointegration and Structural Change. Cambridge: Cambridge University Press.

[27] McCallum, Bennett T., and Marvin S. Goodfriend. (1987) "Demand for money: theoretical studies." In The New Palgrave: A Dictionary of Economics, edited by Eatwell, John, Murray Milgate and Peter Newman, 
pp. 775-781. London: MacMillan, New York: Stockton Press, Tokyo: Maruzen.

[28] Meltzer, Allan H. (1963) "The demand for money: The evidence from the time series." Journal of Political Economy, 71, 219-246.

[29] Mishkin, Frederic S. (2007) "Inflation dynamics." International Finance, $10: 3,317-334$.

[30] Mulligan, Casey B., and Xavier Sala-i-Martin. (2000) "Extensive margins and the demand for money at low interest rates." Journal of Political Economy, 108:5, 961-991.

[31] Pesaran, M. Hashem, and Yongcheol Shin. (1999) "An autoregressive distributed lag modelling approach to cointegration analysis." In Econometrics and Economic Theory in the 20th Century: The Ragnar Fresch Centennial Symposium, edited by Steinar Strøm, pp. 371-413. Cambridge: Cambridge University Press.

[32] Phillips, Peter C.B., and Bruce E. Hansen. (1990) "Statistical inference in instrumental variables regression with $\mathrm{I}(1)$ processes." The Review of Economics and Statistics, 57, 99-125.

[33] Phillips, Peter C.B., and Sam Ouliaris. (1990) "Asymptotic properties of residual based tests for cointegration." Econometrica, 58, 165-193.

[34] Saikkonen, Pentti. (1991) "Asymptotically efficient estimation of cointegration regressions." Econometric Theory, 8:1, 1-27. 
[35] Zivot, Eric. (1994) "A Bayesian analysis of the unit root hypothesis within an unobserved components model." Econometric Theory, 10:3/4, $552-578$. 


\begin{tabular}{lcc|cc}
\hline \hline & & & \\
& \multicolumn{2}{c|}{ HOUSEHOLDS } & \multicolumn{2}{c}{ FIRMS } \\
& Semi-log & Log-log & Semi-log & Log-log \\
\hline & & & & \\
& & & $-3.619^{*}$ & $-2.552^{*}$ \\
Zivot's two-step ECM ${ }^{a}$ & $-3.837^{*}$ & $-3.915^{*}$ & $19.217^{*}$ & $13.146^{*}$ \\
Zivot's one-step ECM ${ }^{b}$ & $13.676^{*}$ & $12.479^{*}$ & & \\
& & & $-3.680^{\dagger}$ & -3.134 \\
Phillips-Ouliaris $Z_{t}^{c}$ & $-3.660^{\dagger}$ & $-3.383^{\dagger \dagger}$ & $-24.588^{\dagger}$ & -17.970 \\
Phillips-Ouliaris $Z_{q}^{c}$ & $-26.003^{\dagger}$ & $-22.182^{\dagger \dagger}$ & & \\
\hline \hline
\end{tabular}

Notes: $*, \dagger, \dagger \dagger$, denote statistical significance at the $5 \%, 10 \%$ and $15 \%$ critical levels, respectively

a) The statistic for Zivot's two-step ECM-based test is distributed as a standard $t$-distribution.

b) The statistic for Zivot's one-step ECM-based test is distributed as $\chi^{2}(3)$.

c) The $Z_{q}$ and $Z_{t}$ statistics are computed using the Newey-West estimator of the error variance with lag truncation $q=4$, following the sample-dependent rule $q=4(T / 100)^{2 / 9}$. 
Table 2. Long-run money demand functions of households

\begin{tabular}{|c|c|c|c|c|}
\hline & \multicolumn{2}{|c|}{ LOG-LOG } & \multicolumn{2}{|c|}{ SEMI-LOG } \\
\hline & $\beta$ & $\eta$ & $\beta$ & $\xi$ \\
\hline $\operatorname{DOLS}(2,2)^{a}$ & $\begin{array}{l}0.530^{* *} \\
(0.02)\end{array}$ & $\begin{array}{l}0.118^{* *} \\
(0.02)\end{array}$ & $\begin{array}{l}0.537^{* *} \\
(0.01)\end{array}$ & $\begin{array}{l}2.520^{* *} \\
(0.30)\end{array}$ \\
\hline $\operatorname{ARDL}(2)^{b}$ & $\begin{array}{l}0.536^{* *} \\
(0.03)\end{array}$ & $\begin{array}{l}0.133^{* *} \\
(0.04)\end{array}$ & $\begin{array}{l}0.545^{* *} \\
(0.03)\end{array}$ & $\begin{array}{l}2.521^{* *} \\
(0.84)\end{array}$ \\
\hline FMOLS $^{c}$ & $\begin{array}{l}0.534^{* *} \\
(0.04)\end{array}$ & $\begin{array}{l}0.127^{* *} \\
(0.03)\end{array}$ & $\begin{array}{l}0.528^{* *} \\
(0.03)\end{array}$ & $\begin{array}{l}3.038^{* *} \\
(0.60)\end{array}$ \\
\hline $\mathrm{EY}(2)^{d}$ & $\begin{array}{l}0.522^{* *} \\
(0.01)\end{array}$ & $\begin{array}{l}0.129^{* *} \\
(0.03)\end{array}$ & $\begin{array}{l}0.537^{* *} \\
(0.01)\end{array}$ & $\begin{array}{l}2.562^{* *} \\
(0.79)\end{array}$ \\
\hline
\end{tabular}

Notes: Standard errors in parenthesis. $* *, *$ denote statistical significance at the $1 \%$ and $5 \%$ critical levels, respectively. Number of lags (and leads for DOLS) in levels specified next to the estimator. Newey and West standard errors except for FMOLS (quadratic spectral kernel).

a) Dynamic OLS by Saikkonen (1991).

b) Autoregressive distributed lag model by Pesaran and Shin (1999).

c) Fully modified method of Phillips and Hansen (1990).

d) Engle and Yoo's (1991) three-step Engle and Granger procedure. 
Table 3. Long-run money demand functions of firms

\begin{tabular}{|c|c|c|c|c|}
\hline & \multicolumn{2}{|c|}{ LOG-LOG } & \multicolumn{2}{|c|}{ SEMI-LOG } \\
\hline & $\beta$ & $\eta$ & $\beta$ & $\xi$ \\
\hline $\operatorname{DOLS}(5,5)$ & $\begin{array}{l}0.536^{* *} \\
(0.04)\end{array}$ & $\begin{array}{l}0.220^{* *} \\
(0.05)\end{array}$ & $\begin{array}{l}0.547^{* *} \\
(0.04)\end{array}$ & $\begin{array}{l}4.860^{* *} \\
(0.72)\end{array}$ \\
\hline $\operatorname{ARDL}(2)$ & $\begin{array}{l}0.571^{* *} \\
(0.08)\end{array}$ & $\begin{array}{l}0.195^{*} \\
(0.09)\end{array}$ & $\begin{array}{l}0.568^{* *} \\
(0.06)\end{array}$ & $\begin{array}{l}4.558^{* *} \\
(1.46)\end{array}$ \\
\hline FMOLS & $\begin{array}{l}0.522^{* *} \\
(0.09)\end{array}$ & $\begin{array}{l}0.272^{* *} \\
(0.08)\end{array}$ & $\begin{array}{l}0.521^{* *} \\
(0.06)\end{array}$ & $\begin{array}{l}6.280^{* *} \\
(1.07)\end{array}$ \\
\hline $\mathrm{EY}(2)$ & $\begin{array}{l}0.512^{* *} \\
(0.03)\end{array}$ & $\begin{array}{l}0.182^{*} \\
(0.08)\end{array}$ & $\begin{array}{l}0.534^{* *} \\
(0.01)\end{array}$ & $\begin{array}{l}4.589^{* *} \\
(1.33)\end{array}$ \\
\hline
\end{tabular}

Note: See notes to Table 2. 
Table 4. Stability tests of sectoral money demand functions

\begin{tabular}{|c|c|c|c|c|}
\hline & \multicolumn{2}{|c|}{ HOUSEHOLDS } & \multicolumn{2}{|c|}{ FIRMS } \\
\hline & Log-log & Semi-log & Log-log & Semi-log \\
\hline MeanF & $\begin{array}{c}1.241 \\
{[p \geq 0.20]}\end{array}$ & $\begin{array}{c}0.967 \\
{[p \geq 0.20]}\end{array}$ & $\begin{array}{c}4.733 \\
{[p=0.14]}\end{array}$ & $\begin{array}{c}4.419 \\
{[p=0.17]}\end{array}$ \\
\hline SupF & $\begin{array}{c}3.070 \\
{[p \geq 0.20]}\end{array}$ & $\begin{array}{c}2.557 \\
{[p \geq 0.20]}\end{array}$ & $\begin{array}{c}8.286 \\
{[p \geq 0.20]}\end{array}$ & $\begin{array}{c}7.886 \\
{[p \geq 0.20]}\end{array}$ \\
\hline
\end{tabular}

Notes: Tests based on fully modified OLS estimates over the sample's

trimmed region $[0.15,0.85]$. P-values are based on asymptotic distributions calculated using Monte Carlo simulations by Hansen (1992). 
Table 5. Welfare cost of inflation for households (as a percentage

\begin{tabular}{|c|c|c|c|c|c|c|}
\hline \multicolumn{7}{|c|}{ of consumption) } \\
\hline & \multicolumn{3}{|c|}{ LOG-LOG } & \multicolumn{3}{|c|}{ SEMI-LOG } \\
\hline & $w(0.15)$ & $w(0.05)$ & $\Delta w$ & $w(0.15)$ & $w(0.05)$ & $\Delta w$ \\
\hline DOLS & 0.23 & 0.09 & 0.14 & 0.33 & 0.04 & 0.29 \\
\hline ARDL & 0.26 & 0.10 & 0.16 & 0.33 & 0.04 & 0.29 \\
\hline FMOLS & 0.25 & 0.09 & 0.15 & 0.39 & 0.05 & 0.34 \\
\hline $\mathrm{EY}$ & 0.25 & 0.10 & 0.15 & 0.33 & 0.04 & 0.29 \\
\hline
\end{tabular}

Note: Model specifications as in Table 1. 
Table 6. Welfare cost of inflation for firms (as a percentage of business GDP)

\begin{tabular}{|c|c|c|c|c|c|c|}
\hline & \multicolumn{3}{|c|}{ LOG-LOG } & \multicolumn{3}{|c|}{ SEMI-LOG } \\
\hline & $w(0.15)$ & $w(0.05)$ & $\Delta w$ & $w(0.15)$ & $w(0.05)$ & $\Delta w$ \\
\hline DOLS & 0.19 & 0.08 & 0.11 & 0.26 & 0.04 & 0.22 \\
\hline ARDL & 0.17 & 0.07 & 0.10 & 0.24 & 0.04 & 0.21 \\
\hline FMOLS & 0.24 & 0.11 & 0.13 & 0.31 & 0.05 & 0.26 \\
\hline $\mathrm{EY}$ & 0.16 & 0.06 & 0.09 & 0.24 & 0.04 & 0.21 \\
\hline
\end{tabular}

Note: Model specifications as in Table 2. 
Table 7. Welfare gains from a ten percentage point reduction in

\begin{tabular}{|c|c|c|c|c|c|c|}
\hline & \multicolumn{2}{|c|}{ HOUSEHOLDS } & \multicolumn{2}{|c|}{ FIRMS } & \multicolumn{2}{|c|}{ AGGREGATE } \\
\hline & Log-log & Semi-log & Log-log & Semi-log & Log-log & Semi-log \\
\hline$w(0.13)$ & $0.13 \%$ & $0.17 \%$ & $0.13 \%$ & $0.16 \%$ & $0.26 \%$ & $0.33 \%$ \\
\hline$w(0.03)$ & $0.03 \%$ & $0.01 \%$ & $0.04 \%$ & $0.01 \%$ & $0.07 \%$ & $0.02 \%$ \\
\hline$\Delta w$ & $0.10 \%$ & $0.16 \%$ & $0.09 \%$ & $0.15 \%$ & $0.19 \%$ & $0.31 \%$ \\
\hline
\end{tabular}

Note: Estimates of welfare costs obtained using DOLS specifications in Tables 2 and 3. 